\title{
Various Concepts to Acquire the Skills
}

\author{
U. Sreerekha
}

M.A, M.Phil., B.Ed., Assistant Profess or, Department of English, Veltech Multitech, Dr Rangarajan Dr Sakunthala Engineering College, Avadi, Chennai, India

\begin{abstract}
A language is a systematic means of communication. Language is a system for communicating ideas. To be successful, a person requires good communication skills. These skills comprise writing skills, speech skills, listening skills, nonverbal skills. One should have communication skills, while reading, writing, listening, speaking, and conversation with various groups of people etc. Nowadays, all the companies or organizations seek the candidate who speaks good English even for non-voice process jobs because to interact with higher officials through English communication is very essential in the workplace today.
\end{abstract}

Keywords- communication. Language, English communication.

\section{INTRODUCTION}

Language is never learnt, it is acquired. If one wants to acquire language, he/she should follow natural way of learning things. Communication is the life skill, it helps to express and share, to pursue advance or higher studies, to develop a healthy working environment, to lead a team from the front etc., the fulfillment in language acquisition can be attained through Listening Speaking Reading Writing. This paper attempts at a novel idea which emphasizes that the philosophy of learning and teaching the language.

\section{CONCEPT OF LSRW}

The concept of LSRW is redefined here as follows:

$>$ Listening initiates an individual's learning process.

$>$ Speaking, even at the rudimentary level, is the step for rectifying errors and internalizing the acquired language
$>$ Reading fortifies the standards of language and refines it.

$>$ Writing is the ultimate channel for concretizing and customizing the language levels acquired.

LSRW skills are very important and in this $21^{\text {st }}$ century to be literate is to be able to manage communication across languages and cultures.In a multi-lingual society students must also be able to communicate effectively because it enjoys the status of Lingua Franca, has been widely accepted as the most widespread language in the world,it has been cited as the major language of international, business, diplomacy, science and profession. The solution for all these problems is in one-LSRW.

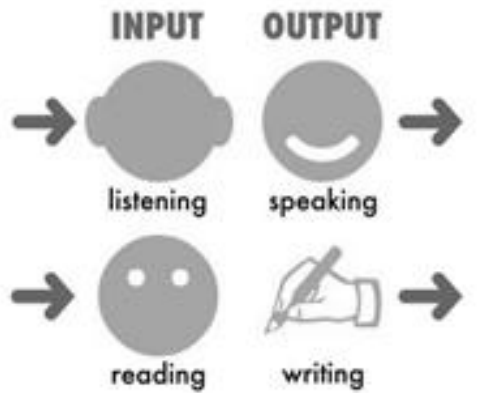

LSRW is the correct order of teaching the skills. The mastery of any language depends mainly on LSRW skills. As the skills are interlinked the avtive skills depend on the passive skills for their fluency and development. Among the four skills, the Speaking and writing are called as active and productive skills; reading and listening are called passive and receptive skills.

\section{REQUIRED TOOLS}

The required tools for teaching these skills are:

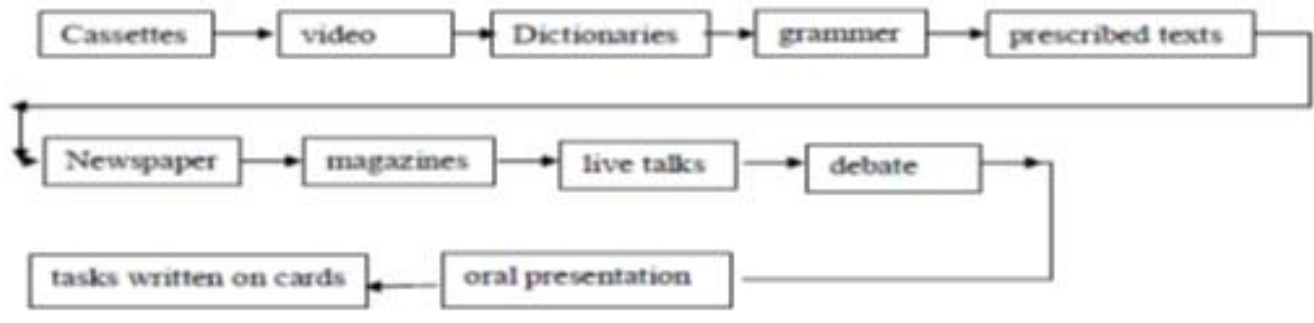




\section{LISTENING}

Listening skills is one of the most important language skills that a person need in order to be successful in their academic and professional pursuits. The process of learning a language starts with listening.listening comprehension is the receptive skill in the oral mode.When we speak of listening what we really mean is listening and understanding what we hear.In our first language, we have all the skills and background what we hear, so we probably aren't even ware of how complex a process it is.

There are two kinds of listening 1.interactive and 2.non-interactive.

Interactive listening situations include face to face conversations and telephone calls,in which we are alternatively listening and speaking, and in which we have a chance to ask for clarification, repetition or slower speech from our conversation partner.Some non-interactive listening situations are listening to the radio, TV ,films ,lectures, or sermons. In such situations we usually don't have the opportunity to ask for clarification.

\section{SPEAKING}

Speaking is the productive skill in the oral mode. It, like the other skills, it also is more complicated than it seems at first and involves more than just pronouncing words. The circumstances involving speaking and listening can be broadly put into three categories:

One-to-one(face to face, on the telephone)

- One to group(seminars, lectures, talks, oral reports, meetings)

- Group to group (meetings, discussions)

An effective speaker can easily influence others and achieve prominence in public life. The audience and context are the factors which decide the pitch, modulation, pace, pause and rhythm of speech. Some of the sub skills of oral communication that one may need to include the following:

\begin{tabular}{|c|c|}
\hline \multicolumn{2}{|r|}{ sv } \\
\hline & Expressing \\
\hline & Comments \\
\hline & $\begin{array}{l}\text { Academic and Professional } \mathrm{O} \\
\text { Interaction }\end{array}$ \\
\hline & $\begin{array}{l}\text { Academic/Professional } \\
\text { discussion }\end{array}$ \\
\hline & Meetings/Conferences \\
\hline & Oral presentations. \\
\hline
\end{tabular}

\section{READING}

Of all these skills reading is the least important .Students at tertiary level have a huge amount of reading to do:some for core information and even more as background to the main subject. It is therefore essential that reading should be done as efficiently as possible. In fact, increasing reading speed may actually improve understanding. There must be an interactive process between the reader and the text in order to extract meaning. Reading can be described as a process of 'sight-sound-sense'. Reading can help build vocabulary that helps listening comprehension at the micro-skills particulary. Ther are some of the micro-skills involved in reading. The reader has to:

$\circ$ Suggest them informative and light reading stuff.

- Ask them to recognize coherence and sequencing of sentences

- Ask them to identify the topic sentence

- Arrange reading comprehension from simple to difficult/familiar to unfamiliar text

- Specific reading techniques: WRITING skimming/scanning/intensive/extensive.

Writing is the productive skill in the written mode. The significance of writing skills cannot be overemphasized because writing is so important for the students of all kinds and professional student, a person need effective writing skills.

- Aim at developing awareness that writing is a formal skill

- Select topic and ask every student to write one sentence on board

- Assign to arrange all the sentences in a proper order individually.

- Give feedback and discuss the importance of coherence, unity and cohesiveness

- Make pairs and task them to write anything that they find interesting.

- To conduct writing workshops on letters, reports, resumes providing samples.

\section{CONCLUSION}

Mastering these four skills increase employability. I conclude by saying that all the above discussed ideas should practically be dealt in the classrooms. For this the number of students in a class should be 35-40.If this done,the level of communication can easily be increased to face the challenges in their professional profile. 


\section{REFERENCES}

[1] Andrea J. Rutherford, Basic Communication Skills for Technology; Pearls on Eduction Aia.2001.

[2] English for Engineers and technologists, Vol 1.Division of Humanities and Social Sciences,Anna University, Oreint Longman ltd,2003.

[3] Farhathullah T.M Communication Skills for Technical students,Chennai, Oreint Longman

[4] Rayudu C.S Communication Himalaya Publishing House,Eighth ,2007

[5] Raman Meenakshi, Sangeetha Sharma "Technical Communication" Principles and Practice Oxford University Press,2004. 